\title{
In Extremis Leadership: A Study of the Effects in Different Contexts
}

\author{
Deirdre P. Dixon \\ University of Tampa
}

Michael Weeks

The Citadel

\author{
Richard Boland, Jr. \\ Case Western Reserve University \\ James Gaskin \\ Brigham Young University
}

When lives are at stake, astutely reading a situation (situation awareness) and belief in one's ability to manage it (self-efficacy) are crucial leadership skills. Fire fighters, law enforcement officers and military leaders routinely enter dangerous, in extremis, situations. Data from these environments is difficult to capture, so there is a gap in the literature looking at the distinctness of these professions. We report on a survey of 514 military, firefighting, and law enforcement leaders examining their experiences during in extremis conditions. This study examines the moderating effect of four human qualities identified in that study (self-esteem, self-sacrifice, mental flexibility and altruism) on situation awareness and self-efficacy as they relate to performance in life threatening situations. We theorize and show in our research that differing priorities among the organizational missions give rise to disparities among the groups. Instead of routinely looking at all in extremis occupations as one population with identical roles, research into these differences should be explored further. Results thus seem relevant to most organizations facing lifethreatening situations, and each distinct group may benefit from different criteria for hiring, recruiting and training of personnel. The results may also be of interest to individuals facing tense, ambiguous, albeit less acute, circumstances.

Keywords: In Extremis Leadership, Situation Awareness, Self-efficacy, Military, First responders

\section{INTRODUCTION}

Interest in critical incident leadership, particularly military combat operations, has escalated for more than a decade (Campbell, Hannah, \& Matthews, 2010; Laurence \& Matthews, 2012; Wong, Kolditz, Millen, \& Potter, 2003). Critical incident research also extends beyond military operations to fire fighters (Baran \& Scott, 2010; Hytten \& Hasle, 1989; Ramthun \& Matkin, 2014; Weick, 1993), law enforcement personnel (Bechky \& Okhuysen, 2011; Johnson et al., 2011; Murphy, 1965) and other first responders 
(Graen \& Graen, 2013; Kolditz, 2006, 2007; Sweeney, Matthews, \& Lester, 2011). Previous research adds tremendous value and insight toward improving the effectiveness and efficiencies of many important organizations, yet many significant issues remain unresolved. For example, fire fighters have faced increased fatalities in the past few years, prompting calls for more human factors research (Lewis, 2013). The dynamic in extremis environment coupled with the complexity of human cognition and agency require additional research to understand the effects of leaders' performances on personal and organizational outcomes.

Our study examines a subset of critical incident leadership situations, in extremis environments. In extremis leadership situations are those in which the life of the leader and the team are in peril during operations. We assume that these environments have fundamental differences from traditional leadership environments, and even other critical incident environments like emergency rooms where a life or lives are at stake, yet the leader and team are not in imminent peril. Leadership in extremis warrants special attention due to the heightened psychological stresses and other leadership concerns inherent in these environments (Dixon, Weeks, Boland Jr, \& Perelli, 2016; Geier, 2016; Hannah, Uhl-Bien, Avolio, \& Cavarretta, 2009; Watters, 2017).

Empirical research on people in situ in these dangerous environments is challenging (Hannah et al., 2009), yet the potential for real life-saving returns from such research on leadership in extremis contexts compels examination. The "felt experience" using the leaders' own thoughts and words is lacking (K. Fisher \& Robbins, 2015, p. 4). To address this gap, in lieu of actually being present in these environments in situ, phenomenological interviews with individuals leading in extremis environments as well as surveys can aid understanding of these dangerous situations and how individuals can improve both personal and team performance.

This project began by interviewing thirty U.S. Army soldiers that had recently returned from combat zones in the Middle East. We asked them to reflect on a time when they were in an extreme situation, and then expound upon it. These soldiers understood their lives were at stake, and their first-person accounts provide remarkable insights into how real-life heroes made enough sense of extraordinary conditions to live and tell about it. From these initial interviews, we then expanded our research.

The research involved four general stages. First, a grounded theory analysis (Corbin \& Strauss, 2008) was conducted on the transcripts of the initial Army interviews to codify how and why leaders were successful in these in extremis environments. Second, those qualitative results led to development of a research model and survey to explore the findings from the qualitative study further. Third, the research was then expanded to include all branches of the United States military. A final survey was then administered to a broader group of leaders including military members, fire fighters, and law enforcement personnel.

This article reports our findings from the fourth phase of the research and includes military and nonmilitary leaders. Specifically, survey responses from 123 law enforcement officers and 191 fire fighters are compared with those of 200 of the military respondents. The focus of this study is on the association of personal characteristics, derived from the qualitative study, with situation awareness and self-efficacy.

Our research posits that a leader's ability to quickly and insightfully assess a dangerous situation and a strong belief in one's ability to do what is required to resolve it are associated with positive in extremis outcomes. An important question this research examines is, "How might individual characteristics affect this ability and belief for various in extremis occupations?" Surprising results show that although all in extremis groups are normally classified together (Sweeney et al., 2011), there are differences among the various groups examined in this study. Our research suggests that the raison d'être of the organization matters when examining in extremis environments. 


\section{THEORETICAL FRAMEWORK}

\section{In Extremis Context}

Leadership in dangerous environments requires exigencies and urgency not present in ordinary life (Campbell et al., 2010; Palmer, Hannah, \& Sosnowik, 2011). The in extremis context refers to situations where leaders believe their lives are "at the point of death" (Kolditz, 2006, p. 657). In extremis situations can occur across various organizations (Hannah \& Lester, 2009), but hazardous occupations such as law enforcement, military service, and firefighting routinely involve in extremis situations.

Our leadership research is bound by this distinctive in extremis context, with the supposition that context matters. Leadership in life-threatening situations may be paramount, but the difficulty in collecting data in these environments has led to a dearth of research on performance in in extremis environments. Accordingly, we believe more research in this context is needed (Baran \& Scott, 2010; Campbell et al., 2010; Dixon et al., 2016). The military focuses on this context for obvious reasons, while fire fighters and police tend to look to military service for in extremis research (Lewis, 2013), which is not always the best approach (Cowper, 2000).

The in extremis context overwhelms most leaders with information that must be processed quickly for effective action. Situation awareness has been identified as a critical factor in performing effectively in most leadership tasks (Endsley \& Garland, 2000), and Weick (1993) reported that the chaos of crises can break down the situation awareness in teams. Baran and Scott (2010) added that leaders play an important role in teams in dangerous contexts through communications and understanding each member's role in the team. What has not been studied in depth are how the characteristics and behavior of the leader impact situation awareness during these turbulent environments, although it has been identified that firefighters (G. A. Klein, Calderwood, \& Clinton-Cirocco, 1986; Lewis, 2013), military (Matthews, 2012) and police (Sweeney et al., 2011) would benefit from general increased situation awareness.

Our premise for this research is that this in extremis context matters for leaders. The fundamental underpinning of this research is about leadership and how leaders react when their lives are in danger. We believe that the leadership in these extreme contexts will be different from other types of leadership, but similar among in extremis occupations.

We also believe that some of these results may have relevance beyond the in extremis environment. Extreme contexts vary greatly. Some problems may not be life threatening; yet, dilemmas like organizational survival and job elimination can create stresses that have many similarities to in extremis situations.

\section{Situational Leadership}

Context matters, yet the foundation of this research is about leadership. Theorists have moved beyond trait leadership theory - the idea that the possession of certain traits define effective leaders (Bass \& Bass, 2008; G. Yukl, 2002). Situational Leadership Theory (Hersey \& Blanchard, 1969) explains that there is no one appropriate style of leadership; leadership depends on the situation, and different situations require the leader to adapt with different types of leadership. The situation is also important; Vroom and Yetton (1973) found that the nature of the leadership situation caused three times the variance compared to individual trait differences.

Other research has supposed it's not just about the situation, but also about the construction of the context (Grint, 2005). Our idea is that effective leadership depends more upon the situational context than upon a leader's personality traits. Circumstances, social construction, and social context dictate behavior because "situational forces have the larger effect when pitted against the person's inclinations or desires" (Vroom \& Jago, 1995, p. 179). Our research explores factors that affect a leader's performance in these unusual environments.

One of these factors is a leader's response to stress (Martin M Chemers \& Ayman, 1993). Effective leader behaviors are linked to whether the leader's reaction suits environmental demands (Fiedler, 1993). When leaders are under stress, leadership requirements differ from more staid conditions (Bass \& Bass, 2008). Thus, an in extremis context surely evokes stress, often attributed to the leader's lack of control 
over situational factors (previous study) and the leader's concern for his own survival. Respondents in this study reported experiencing elevated levels of stress under varying situations. Situational leadership theory suggests their decisions would be driven by the situation at hand (Miner, 2002).

\section{Interdependency between the Leader and the Context}

Our research posits that there is an interdependency between the in extremis context and leader traits. We used the previous qualitative research to identify several traits for examination. Additionally, several conditions warranted consideration to improve the study's validity in isolating what was occurring. For model completion, common control variables for leadership research included age, education, and gender. The in extremis component accounts for different amounts of in extremis experience within our sample, attempting to standardize factors. These standard controls have been included since they may affect leadership performance.

After identifying several factors from our grounded examination of interview data, we sought to anchor our survey in the current literature. Consequently, this paper builds on prior literature which establishes that self-efficacy (Bandura, 1997; Ericsson, Charness, Feltovich, \& Hoffman, 2006; Feltz \& Weiss, 1982; Laurence \& Matthews, 2012; Sweeney et al., 2011) and situation awareness (Bandura, 1982; Endsley \& Garland, 2000; Ericsson et al., 2006; Ericsson, Krampe, \& Tesch-Römer, 1993; Matthews, 2012; Sweeney et al., 2011) link positively to outcomes within in extremis environments.

Our paper investigates how differing individual and demographic characteristics can affect situation awareness and self-efficacy when a leader's life is in danger. Elaboration involves two fundamental research questions, which are graphically illustrated in Figure 1:

- How do characteristics associated from the literature on first responder performance (flexibility, altruism, self-sacrifice and self-esteem) relate to the two factors (situational awareness and self-efficacy) suggested as characteristics of leadership success during in extremis outcomes?

- Are there differences conditioned on the first-responder's occupational category (firefighters, military personnel and law enforcement)?

\section{Self-efficacy}

Much of the literature on self-efficacy - the central component of Bandura's social cognitive theory-focuses on relationships between environmental influences, self-precepts of efficacy and action. In this context, self-efficacy precepts are seen to affect "thought patterns, actions, emotional arousal" and performance accomplishments (Bandura, 1982, p. 122). Self-efficacy denotes a perceived capacity for learning or completing actions at certain levels (Bandura, 1997). According to Bandura and Locke (2003, p. 1), no mechanism of human agency "is more central or pervasive than beliefs of personal efficacy...rooted in the core belief that one has the power to produce desired effects; otherwise one has little incentive to act or to persevere in the face of difficulties."

Bandura's (1982) seminal work on self-efficacy in human agency has been examined with a plethora of prior research in many fields. The research has shown a stable affirmative link between self-efficacy and various types of performance in areas such as sports (Moritz, Feltz, Fahrbach, \& Mack, 2000), newcomers to a job (Saks, 1995), social workers (Holden, Meenaghan, Anastas, \& Metrey, 2002), academics (Multon, Brown, \& Lent, 1991) and work performance (Sadri \& Robertson, 1993). As relates to our research, the study of leadership has also shown links from self-efficacy to outcomes or performance as a manager (M.M. Chemers, Watson, \& May, 2000; Hannah, 2006; Lent et al., 2008; Paglis \& Green, 2002; Sadri \& Robertson, 1993).

A strong belief in one's performance efficacy is essential in mobilizing and sustaining the effort necessary to succeed (Bandura, 1997). As such, self-efficacy can be developed and trained through experiences and role models, and it is not a trait-like characteristic (Bandura, 1982; Feltz \& Weiss, 1982). Enhanced performance from self-efficacy is important during life threating situations since time is critical, so we hypothesize the following in the model (see Figure 1). 


\section{Situation Awareness}

Situation awareness reflects information an individual surmises about a situation (Endsley, 1995a, 1995b; Strater, Endsley, Pleban, Matthews, \& TRW Inc Fairfax VA Systems Information Technology Group, 2001) and how she or he uses that knowledge to envisage a future state (Jensen \& Brehmer, 2005; Matthews, 2014). Situation awareness is "an intermediate state in the decision-making process of dynamic systems where one should be able to comprehend the situation in order to make an appropriate decision for future development" (Artman \& Garbis, 1998). Because of the importance of appraising and interpreting an acute threat environment, occupations whose leaders encounter in extremis situations rely on situation awareness to decipher both what is occurring now and what may occur (Endsley \& Garland, 2000; Matthews, 2012; Sweeney et al., 2011). Hazardous occupations to include emergency management (Kozlowski, Gully, Salas, \& Cannon-Bowers, 1996), military (Matthews, 2012; Strater et al., 2001), law enforcement (Salmon, Stanton, Walker, \& Green, 2006) and firefighting (Dow, Garis, \& Thomas, 2013; Salmon et al., 2006; Wellens, 1993) believe situation awareness is important for their leaders, with numerous researchers looking at two or more of the groups together. Still other researchers focus on examining team situational awareness (Fernandez et al., 2008; Salas, Prince, Baker, \& Shrestha, 1995). Our research looks at the unit of analysis from the individual level. Baard, Rench and Kozlowski (2014) have indicated that individual performance during crisis situations can be changed by things that individuals experience and learn. Our model hypothesizes that situation awareness is vital during in extremis conditions and is affected by an individual's prior experience, as can be seen in Figure 1.

\section{Characteristics}

Because our prior research and the literature revealed self-efficacy and situation awareness can have positive effects on outcomes, our next step provides a more detailed examination of the literature concerning the personal leader characteristics that may have an explicit effect on self-efficacy and situation awareness. These characteristics were all derived from the initial qualitative study when respondents were asked about their success in dangerous environments and their responses included mental flexibility, self-confidence (which we operationalized as self-efficacy) and sense of duty (which we determined to be a combination of both altruism and self-sacrifice).

\section{Flexibility}

Being mentally flexible and adaptable have long been admired leadership traits across the business spectrum (Bar-On \& Parker, 2000; Copeland, 1998; Groysberg, Hill, \& Johnson, 2010; K. Klein, Ziegert, Knight, \& Xiao, 2006). Flexibility "makes it possible to adapt or respond to change, to be influenced, to make modifications and variations" (Scarnati, 1999, p. 194). Researchers of emergency and disaster responses have indicated that flexible leadership is vital for effectiveness (Goldsmith \& Eggers, 2004; Waugh \& Streib, 2006), as well as in law enforcement (Shusta, Levine, Harris, \& Wong, 2002). Having a flexible mindset has also been shown to be beneficial for US Navy Sea Air and Land (SEAL) commandos (Fraher, Branicki, \& Grint, 2017).

\section{Altruism and Self-sacrifice}

Two key cognitive and motivational variables from our qualitative respondents' sense of duty were their willingness to put themselves on the line, self-sacrifice, and their wiliness to help others, altruism. Duty in the literature has mainly been ignored or discussed in relationship to ethical decision making (Hannah, Jennings, Bluhm, Peng, \& Schaubroeck, 2014). Duty orientation (Hannah et al., 2014) comes the closest to what our respondents discussed when talking about the importance of the sense of duty. We will examine these factors of self-sacrifice and altruism that our respondents discussed in regard to their sense of duty. Altruism is about helping individuals in the job or workplace (Smith, Organ, \& Near, 1983). Altruism is "an individual's personal behavior; for example, being cooperative, helpful, and other instances of extra-role behavior" (Truckenbrodt, 2000, p. 235). It is about behaviors - unexpected or required in doing the job - that help other people. People with the trait of altruism may be more likely to help others, sometimes in dangerous situations. 
A second component of a sense of duty in in extremis environments is self-sacrifice. Firefighters who rush into a burning building not only have altruism, a willingness to help others, but also self-sacrifice. They act with less concern for themselves in order to ensure success of the whole. Consequently, selfsacrifice is the readiness to forego personal rewards or safety to help others (Perry, 1996).

Self-esteem

Respondents repeatedly noted that self-confidence or positive self-esteem represented another important trait for successful leadership during life-threatening activities. Related to this factor is confidence. Confidence is suggested by extant scholarship as helpful for leaders, with reasoning that leadership involves influencing others. Self-confidence and self-esteem assure the leader and his followers that his or her direction is apropos (House \& Aditya, 1997; Locke, 1999; G. A. Yukl \& Van Fleet, 1982)

It is important to note here that self-esteem is different from self-efficacy in that self-efficacy reveals if people believe they can accomplish a task (Bandura, 1982), whereas self-esteem is "a favorable or unfavorable attitude towards oneself" (Rosenberg, 1965, p. 15). Self-esteem "is best employed as a predictor or intervening person variable..." (Robinson, Wrightsman, \& Andrews, p. 117). Self-efficacy is more contextual and self-esteem is more personal.

Over the years, self-esteem has been used as a precursor to germane outcomes in a myriad of fields such as job satisfaction, job performance, and motivation (M.M. Chemers et al., 2000; Judge \& Bono, 2001), academic performance (Marsh, 1990) and as helpful with regard to stress (Baumeister, Campbell, Krueger, \& Vohs, 2003; Ganster \& Shaubroeck, 1991; Pierce \& Gardner, 2004; van den Berg \& Soeters, 2009). When researching firefighters, Gasaway (2007) has stated that under stress, self-esteem can affect situational awareness by narrowing attention.

Research has shown that if an individual has low self-esteem, he or she is more unwilling to accept risk, and conversely, if a person has high self-esteem he or she is more willing to take risks (Baumeister, Tice, \& Hutton, 1989), which may help in dangerous situations. While researching fire fighters, Gasaway (2007) stated that under stress, self-esteem can effect situational awareness by narrowing attention.

\section{RESEARCH MODEL AND HYPOTHESES}

The foundation that both situation awareness and general self-efficacy have been shown in various contexts to have a positive effect on outcomes form the basis for this study, along with our prior qualitative research. Examining the antecedent characteristics of these two constructs may prove beneficial. Our research question included investigating what could benefit first responder performance on these two variables. Analyzing our initial interviews led us to examine three elements that leaders indicated helped them be successful when their life was in danger, a sense of duty, self-esteem, and mental flexibility. We also examined the differences based on occupational category. Accordingly, we conjecture that these characteristics will positively influence both situation awareness and self-efficacy in all three of our in extremis groups: military, firefighters and law enforcement.

Hypotheses 1, 2, and 3. The traits of flexibility (H1), self-esteem (H2) and altruism (H3) will have a direct positive effect on situation awareness.

Self-efficacy has also proven to have consistent positive effect on performance through several metaanalysis reviews (Holden, 1992; Multon et al., 1991; Stajkovic \& Luthans, 1998). Bandura (1997) alone has reviewed well over 1000 studies showing self-efficacy does impact performance.

Our linkage of self-efficacy to antecedents of the four characteristics also has precedence. Selfefficacy and mental flexibility, or the ability of an individual to modify his emotions under varying circumstances has been well documented (Martin \& Anderson, 1998; Martin \& Rubin, 1995). Flexibility, an emotional intelligence construct in many models, has been labeled cognitive flexibility (Martin \& Anderson, 1998; Martin \& Rubin, 1995), intellectual flexibility (Gecas, 1989; Kohn, 1989) and emotional 
fitness (Cooper \& Sawaf, 1998). This greater mental flexibility leads to heightened self-efficacy (Gecas, 1989).

Altruism, or one's propensity to help others, has also been linked positively to self-efficacy, as volunteers tend to see themselves and competent and able accomplish tasks (Allen \& Rushton, 1983; Giles, McClenahan, Cairns, \& Mallet, 2004). Our research follows this line of thinking and our hypotheses propose altruism will have a positive effect on self-efficacy.

Leader self-sacrifice has been linked clearly with leadership effectiveness (Cremer \& Knippenberg, 2004; Van Knippenberg \& Van Knippenberg, 2005) and to self-efficacy, leading our hypothesis saying that self-sacrifice will have a positive effect on self-efficacy.

High self-esteem has long been associated positively with job performance (for meta anaylsis see Judge \& Bono, 2001) and job satisfaction (Bono \& Judge, 2003). Research also has highlighted that leaders with high self-esteem respond more positively during conflict situations (Brockner, 1988). Leaders during in extremis conditions are often in difficult situations that may benefit from high selfesteem. Thus, we hypothesize that self-esteem will have a positive effect on self-efficacy.

Hypotheses 4, 5, 6 and 7. The traits of flexibility (H4), self-sacrifice (H5) self-esteem (H6) and altruism (H7) will have a direct positive effect on self-efficacy.

See Figure 1 below for illustration of the hypotheses.

FIGURE 1

MODEL WITH HYPOTHESES

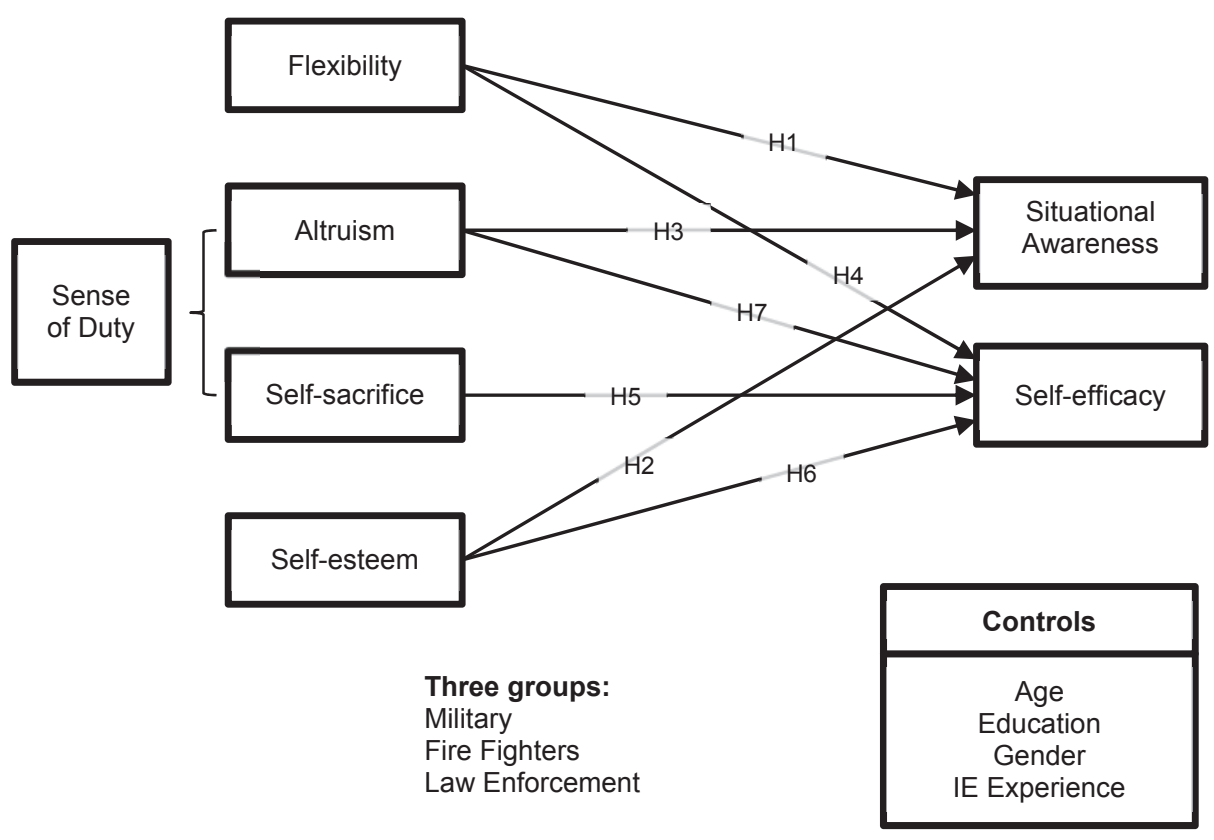

\section{RESEARCH DESIGN AND METHODS}

We employed a psychometric survey methodology (Guilford, 1954) that maps individual responses to the concepts in our model. As our study context was individuals facing life-threatening choices, our respondents came from three groups, military, fire fighters and law enforcement. Each group was run separately through the model, then together. 


\section{Measurement of Research Variables}

Leveraging existing research, we used constructs operationalized from existent literature to test our research model. Each of our respondents was part of a team and their role was either the leader (92\%) or the assistant leader (8\%). A summary of each measure used is provided in Appendix A.

\section{Construct Operationalization}

Our Situation Awareness variable was derived from the SART scale (Endsley \& Garland, 2000), which has 10 generic constructs and three broad domains. We chose to focus on the three broad domains with the abbreviated scale, following Taylor's (1990) comment to use the shorter scale when it is more "advantageous" (Endsley \& Garland, 2000, p. 118). The three situation awareness domains were broken up into demand - which examined how complex the situation was at the time, and supply-focusing on the mental ability of the individual. The final domain was understanding - this idea focused on one's understanding of the information coming in during the situation. We chose not to include this domain since it is a self-report instrument and we thought the survey respondents may not be as objective when asked about how well they understood the situation at the time. Our focus was on the attention of the individual on the variables of the situation. This focus aligns with two of the three levels of situation awareness: Level 1, perception of the situation, and level 2, comprehension of the situation (Laurence \& Matthews, 2012).

Our next dependent variable, Self-Efficacy, was operationalized with the New General Self Efficacy Scale (Chen, Gully, \& Eden, 2001). To streamline, in this paper we refer to this as self-efficacy.

Our independent variables, the characteristics, all had existing scales. Flexibility came from Bar-On's (1996) Emotional Quotient Inventory. Individuals who score high on this scale have a heightened ability to amend their emotions, thoughts and behaviors to varying circumstances (Bar-On, 1996). Altruism is how willing you are to go above and beyond to help others. This scale inquires individuals on their past and possible future behaviors. Self-Sacrifice differs from altruism as it focuses on the willingness of an individual, not just to help the other person, but to sacrifice himself for others. Individuals with high scores on this scale have a concern about the good of society, or doing their duty, over their safety (Perry, 1996).

Finally, Self-esteem, developed from Rosenberg's (1965) scale on an individual's self-worth. Selfesteem levels are consistent over time within individuals, and it is a good "predictor" variable (p. 117).

Controls - Additionally, our model recognizes fairly standard controls in leadership research, things that could possible influence the outcomes. Age, experience, and education have been normal validations of successful leadership, organizations tend to promote based in part on these attributes (Bass \& Bass, 2008). Experience in this survey was based on the amount of times an individual had personally been in in extremis situations. We wanted to compare those that had only encountered danger once versus those that had faced danger frequently. Although research has generally failed to establish gender differences in leadership styles and effectiveness once the leader status has been achieved (Bass \& Bass, 2008; Northouse, 2013), we chose to control for gender because of the usually male dominated domains that we were researching. Indeed, less than ten percent of the respondents in each occupation were women.

Where necessary, we adapted the existing measures to the military/in extremis vernacular and then validated these changes using Bolton's (1993) approach of listening to three pertinent respondents read the questions aloud to assess comprehensibility and ambiguity. If meanings were not clear, we made appropriate adjustments to the instrument. As a consequence of these pretests, we altered two of the items, deleting two questions. To standardize the similarity of the responses, a 5-point Likert scale was used, ranging from "Strongly Disagree" to "Strongly Agree." Only demographic data deviated from this format. Items for each of the constructs are summarized in Appendix A. We also transposed the questions that were reverse coded.

\section{Sample}

Our respondents were sourced from Facebook and Linked-in posts and from links posted on 36 online group sites targeting Veterans (examples: Bronze Star Medal Recipients, 82 ${ }^{\text {nd }}$ Airborne Division 
Veterans, Connected Marines), Fire fighters (examples: fire fighter nation, fire house.com), and Law enforcement (examples: police connect, National Tactical Officers Association). The first author, a retired Army officer, also sent the survey link with a personal note to 175 military, 93 firefighters and 158 law enforcement associates in her network.

Any members of these groups who had been a leader or assistant leader on a team during at least one in extremis situation during their careers were eligible to take the survey. Five hundred and fifty-three responses yielded 494 useable military surveys. Most (426) were completed by members of the U.S. Army. Nineteen Marines, 22 Air Force, 22 Navy and five Coast Guard members also participated. Almost half $(49 \%)$ of respondents were 48 years or older. Fewer than $8 \%$ of respondents were female. This number of women is in line with the amount who have been awarded the Combat Action Badge, with is $9 \%$, for soldiers who are "personally present and actively engaging or being engaged by the enemy" ("Army Human Resources Command," 2017; Sisk, 2015). These surveys were then randomly sampled by Qualtrics to select 200 military responses.

Firefighters had 289 useable surveys and law enforcement personnel yielded 288 surveys. By nature of the chain of command, military units are always arranged in teams. Fire fighters also rarely go into a situation alone. Law enforcement personnel, however, can easily be faced with life threatening situations by themselves. Due to this dichotomy, we wanted to focus on only leaders and assistant leaders of teams. Once we selected for this discriminator the final numbers were 191 fire fighters and 123 law enforcement personnel.

The demographics of our respondents in all occupations reveal that they are mainly older, welleducated males. Almost half (46\%) of these seasoned leaders have been in in extremis environments over six times. See Table 1 for a full report of demographics.

TABLE 1 SAMPLE DEMOGRAPHICS

\begin{tabular}{|l|l|c|c|}
\hline Construct & Value & $\#$ & $\mathbf{\%}$ \\
\hline \multirow{5}{*}{ Occupation } & Military & 200 & $39 \%$ \\
\cline { 2 - 4 } & Fire Fighter & 191 & $37 \%$ \\
\cline { 2 - 4 } & Law Enforcement & 123 & $24 \%$ \\
\hline \multirow{5}{*}{ Education } & Male & 476 & $93 \%$ \\
\cline { 2 - 4 } & Female & 38 & $7 \%$ \\
\cline { 2 - 4 } & Total & 514 & $100 \%$ \\
\cline { 2 - 4 } & GED/High School & 48 & $9 \%$ \\
\cline { 2 - 4 } & Associates Degree & 99 & $19 \%$ \\
\cline { 2 - 4 } & 4 Year Degree & 159 & $31 \%$ \\
\cline { 2 - 4 } & Master's Degree & 183 & $36 \%$ \\
\cline { 2 - 4 } & Doctorate Degree & 25 & $5 \%$ \\
\hline \multirow{5}{*}{ IE Experience } & $18-23$ & 0 & $0 \%$ \\
\cline { 2 - 4 } & $24-29$ & 10 & $2 \%$ \\
\cline { 2 - 4 } & $30-35$ & 39 & $8 \%$ \\
\cline { 2 - 4 } & $36-41$ & 56 & $11 \%$ \\
\cline { 2 - 4 } & $42-47$ & 115 & $22 \%$ \\
\cline { 2 - 4 } & 48 and over & 294 & $57 \%$ \\
\cline { 2 - 4 } & 1 time in an extremis environment & 28 & $5 \%$ \\
\cline { 2 - 4 } & $2-3$ times total in in extremis environment & 98 & $19 \%$ \\
\cline { 2 - 4 } & $4-5$ times total in in extremis environment & 76 & $15 \%$ \\
\cline { 2 - 4 } & 6 times total in in extremis environment & 27 & $5 \%$ \\
\cline { 2 - 4 } & Over 6 times total in in extremis environment & 235 & $46 \%$ \\
\cline { 2 - 4 } & I'd rather not say & 50 & $10 \%$ \\
\hline
\end{tabular}




\section{Statistical Analysis}

The data were analyzed using Statistical Product and Service Solutions (SPSS, version 21) for windows and Analysis of Moment Structures (AMOS, version 21). The initial data set of 867 responses was screened to ensure statistical assumptions could be made with confidence (Mertler \& Vannatta, 2005). Accordingly, we checked for missing data, outliers, normality, linearity, homoscedasticity and multicollinearity. The missing data for each variable was less than .2\%, and there were no outliers. Since our data was derived from Likert-type scales, we had no reason to eliminate variables based on skewness unless they displayed no variance. Instead, we checked to ensure no standard deviations of less than 0.5 for any variable (which would indicate that the majority of responses fell right on the mean-i.e., displaying insufficient variance or kurtosis). Interval variables had standard deviations all above 0.8 , with most over 1.0, indicating no univariate normality issues in our Likert-scale items that might affect results. The data showed sufficient quality to proceed to explore the measurement model.

\section{Measurement Model}

We performed an exploratory factor analysis (EFA), a procedure that describes data by grouping variables that are associated (Mertler \& Vannatta, 2005) using Principle Axis Factoring with Promax rotation. An EFA is normally used to explore the underlying factor structure of data without presuming a structure to start (Suhr \& Colorado, 2006). We examined the variable loadings, adequate correlations, and checked reliability and validity in our conceptual model as described next.

Adequacy

See Table 2 for adequacy details.

TABLE 2

ADEQUACY STATISTICS

\begin{tabular}{|l|l|}
\hline Adequacy Statistics \\
\hline Name & Value \\
\hline KMO & .874 \\
\hline Bartlett's test of Sphericity & 0.0 \\
\hline Communalities & Average value .58 \\
\hline Non-Redundant Residuals & 4 or $1 \%$ \\
\hline Total Variance Explained & $54 \%$ \\
\hline
\end{tabular}

Although low factor loadings are acceptable for so large a sample (514), values over ".5 are considered necessary for practical significance" (Hair, Black, Babin, \& Anderson, 2010, p. 118). Table 3 includes the Pattern Matrix. 
TABLE 3

PATTERN MATRIX

Pattern Matrix ${ }^{a}$

\begin{tabular}{|c|c|c|c|c|c|c|}
\hline & \multicolumn{6}{|c|}{ Factor } \\
\hline & $\mathrm{SE}$ & SS & Flex & SA & ALT & SEFF \\
\hline $\begin{array}{l}\text { SA1 } \\
\text { SA2 } \\
\text { SA7 } \\
\text { A1 } \\
\text { A2 } \\
\text { A6 } \\
\text { SE1 } \\
\text { SE2 } \\
\text { SE5 } \\
\text { SE6 } \\
\text { SEFF2 } \\
\text { SEFF5 } \\
\text { SEFF6 } \\
\text { SS1 } \\
\text { SS4 } \\
\text { SS6 } \\
\text { SS7 } \\
\text { SS8 } \\
\text { F2 } \\
\text { F4 } \\
\text { F6 }\end{array}$ & $\begin{array}{l}.713 \\
.720 \\
.799 \\
.925\end{array}$ & $\begin{array}{l}.691 \\
.663 \\
.662 \\
.589 \\
.736\end{array}$ & $\begin{array}{l}.698 \\
.766 \\
.693\end{array}$ & $\begin{array}{l}.354 \\
.592 \\
.964\end{array}$ & $\begin{array}{l}.563 \\
.838 \\
.621\end{array}$ & $\begin{array}{l}.577 \\
.863 \\
.741\end{array}$ \\
\hline
\end{tabular}

Extraction Method: Principal Axis Factoring.

Rotation Method: Promax with Kaiser Normalization.

a. Rotation converged in 6 iterations.

\section{Reliability}

Table 4 reports the Cronbach's alpha for the factors in our model-the lowest of which was above 0.68 .

\section{Validity}

Factors demonstrate convergent validity with all loadings above the recommended minimum of 0.30 (lowest average was 0.632) for samples of over 300 (Hair et al., 2010). The factors also demonstrate sufficient discriminant validity, as the correlation matrix shows no correlation above 0.6. There were also no problematic cross-loadings as shown in the pattern matrix above. See Table 4 below for reliability statistics, and Table 5 for factor correlations. 
TABLE 4

CRONBACH'S ALPHA AND FACTOR CORRELATION MATRIX

\begin{tabular}{|l|c|c|c|}
\hline Factor & $\begin{array}{c}\text { Cronbach's } \\
\text { alpha }\end{array}$ & $\begin{array}{c}\text { Number of } \\
\text { Items }\end{array}$ & Specification \\
\hline SA & .68 & 3 & Reflective \\
\hline SEFF & .83 & 3 & Reflective \\
\hline FLEX & .76 & 3 & Reflective \\
\hline SE & .87 & 3 & Reflective \\
\hline SS & .80 & 5 & Reflective \\
\hline ALT & .73 & 3 & Reflective \\
\hline
\end{tabular}

TABLE 5

FACTOR CORRELATION MATRIX

\begin{tabular}{|l|l|l|l|l|l|l|}
\hline Factor & SE & SS & Flex & SA & ALT & SEFF \\
\hline SE & 1.000 & .228 & .332 & .233 & .297 & .597 \\
SS & .228 & 1.000 & .322 & .313 & .535 & .467 \\
Flex & .332 & .322 & 1.000 & .107 & .229 & .402 \\
SA & .233 & .313 & .107 & 1.000 & .467 & .373 \\
ALT & .297 & .535 & .229 & .467 & 1.000 & .505 \\
SEFF & .597 & .467 & .402 & .373 & .505 & 1.000 \\
\hline
\end{tabular}

Extraction Method: Principal Axis Factoring.

Rotation Method: Promax with Kaiser Normalization.

Having identified the six-factor structure for our data, we proceeded to Confirmatory Factor Analysis (CFA). CFA is used to verify structure and test hypotheses to authenticate the relationship between the variables in a model and their underlying latent processes (Mertler \& Vannatta, 2005). See Appendix B for CFA. The model fit for the measurement model was sufficient. (See Appendix C, Table C1 and figures $\mathrm{C} 1-\mathrm{C} 3$ for measurement model and SEM diagram).

We also conducted a means difference test (ANOVA) using the mean-centered factor scores from the CFA. At the $95 \%$ confidence level, we found only situational awareness differed across the three groups $(\mathrm{F}=4.727 ; \mathrm{p}=0.009)$. See Table 6 for complete ANOVA results. 
TABLE 6

ANOVA

\begin{tabular}{|l|l|l|l|l|l|l|}
\hline ANOVA & & $\begin{array}{l}\text { Sum of } \\
\text { Squares }\end{array}$ & df & $\begin{array}{l}\text { Mean } \\
\text { Square }\end{array}$ & F & Sig. \\
\hline Altruism & Between Groups & .059 & 2 & .030 & .196 & .822 \\
\hline & Within Groups & 77.649 & 511 & .152 & & \\
\hline & Total & 77.709 & 513 & & & \\
\hline Flexibility & Between Groups & 1.057 & 2 & .529 & 2.947 & .053 \\
\hline & Within Groups & 91.654 & 511 & .179 & & \\
\hline & Total & 92.711 & 513 & & & \\
\hline Sacrifice & Between Groups & .945 & 2 & .473 & 1.886 & .153 \\
\hline & Within Groups & 128.019 & 511 & .251 & & \\
\hline Esteem & Total & 128.964 & 513 & & & \\
\hline & Between Groups & .347 & 2 & .174 & .740 & .478 \\
\hline & Within Groups & 119.901 & 511 & .235 & & \\
\hline & Total & 120.248 & 513 & & & \\
\hline SE & Between Groups & .146 & 2 & .073 & .383 & .682 \\
\hline & Within Groups & 97.226 & 511 & .190 & & \\
\hline & Total & 97.372 & 513 & & & \\
\hline SitAware & Between Groups & 2.185 & 2 & 1.092 & 4.727 & .009 \\
\hline & Within Groups & 118.063 & 511 & .231 & & \\
\hline & Total & 120.248 & 513 & & & \\
\hline
\end{tabular}

\section{Validity and Reliability of Latent Constructs}

To test for convergent validity we calculated the AVE for all factors (should be greater than 0.500). Three of our constructs, altruism, self-sacrifice and situation awareness did not meet this criteria. However, because each of the constructs is a valuable part of our model, we elected to maintain them even with the slightly low AVE values of .476 for Altruism, .438 for Self-Sacrifice and .498 for Situation Awareness. As is evidenced by Table 7, our model fit is still good and all three of these constructs show sufficient discriminant validity, thus we felt justified in letting the borderline convergent validity measures pass.

TABLE 7

MODEL FIT FOR STRUCTURAL MODEL

\begin{tabular}{|l|l|}
\hline Measure & Our model tested \\
\hline Chi-square/df & $18.462 / 6$ \\
(cmin/df) & 3.077 \\
\hline P value for the model & .005 \\
\hline CFI & .992 \\
\hline GFI & .990 \\
\hline AGFI & .953 \\
\hline SRMR & .031 \\
\hline RMSEA & .064 \\
\hline NFI & .988 \\
\hline PCLOSE & .212 \\
\hline
\end{tabular}


To test for discriminant validity we compared the square root of the AVE (bold on the diagonal in Table 8) to all inter-factor correlations. All factors demonstrated adequate discriminant validity because the diagonal values are greater than the correlations. We also computed the composite reliability for each factor. In all cases, the CR was above the minimum threshold. 0.7 (See Table 8). Our discriminant validity leads us to believe that we do not have any illusionary relationships in our model (Mathieu \& Taylor, 2006).

TABLE 8

VALIDITY AND RELIABILITY OF LATENT CONSTRUCTS

\begin{tabular}{|l|l|l|l|l|l|l|l|l|l|l|}
\hline & CR & AVE & MSV & ASV & SEFF & F & A & SS & SA & SE \\
\hline SEFF & 0.896 & 0.632 & 0.484 & 0.270 & $\mathbf{0 . 7 9 5}$ & & & & & \\
\hline F & 0.767 & 0.524 & 0.202 & 0.105 & 0.449 & $\mathbf{0 . 7 2 4}$ & & & & \\
\hline A & 0.732 & 0.476 & 0.327 & 0.201 & 0.514 & 0.256 & $\mathbf{0 . 6 9 0}$ & & & \\
\hline SS & 0.796 & 0.438 & 0.327 & 0.176 & 0.482 & 0.360 & 0.572 & $\mathbf{0 . 6 6 2}$ & & \\
\hline SA & 0.745 & 0.498 & 0.255 & 0.128 & 0.411 & 0.112 & 0.505 & 0.360 & $\mathbf{0 . 7 0 6}$ & \\
\hline SE & 0.861 & 0.608 & 0.484 & 0.166 & 0.696 & 0.342 & 0.307 & 0.252 & 0.270 & $\mathbf{0 . 7 8 0}$ \\
\hline
\end{tabular}

In Structural Equation Modeling (SEM) it is vital to validate latent measures to ensure valid measurement of the constructs, or confidence in the findings can be place in doubt. As one can deduce from Appendix A, certain items were removed from our various constructs. The primary reason for the removal of these items was the meet criteria for convergent and discriminant validity and reliability, not model fit, although better model fit was a result. This removal of items does not alter the constructs since these factors are reflective versus formative in nature (Jarvis, MacKenzie, \& Podsakoff, 2003).

\section{Common Method Bias (CMB)}

Because all of the variables were collected via a single method (online survey), we conducted a CMB test to determine if a common factor may have been influencing our results. We did not collect data on a social desirability scale, therefore the test we used-one specifically designed for studies that do not measure a common factor - was the common latent factor (CLF) method (Podsakoff, MacKenzie, Lee, \& Podsakoff, 2003). Even after adding the CLF we observed sufficiently strong composite reliability and AVE scores for each construct. When comparing indicator loadings before and after adding the CLF, there were no differences greater than 0.200 ; thus the measurement model is not significantly affected by common method bias (Podsakoff et al., 2003).

\section{Structural Model}

Our structural model was built using composites imputed from latent factor scores obtained from our measurement model (See Table 7). The fitted structural model demonstrates good model fit.

\section{RESULTS}

The results of the hypotheses are presented in Table 9. There are clear paths supported from each of the independent variables to the dependent variables and they are all significant for entire group of 514 . With the R-squares for Situation Awareness equal to .38 and .74 for self-efficacy, this model therefore finds that our human characteristics chosen are essential to both situation awareness and self-efficacy in in extremis situations, all were positive with the exception of flexibility on situation awareness.

Our hypotheses, when looked at with the occupations as groups, examined four characteristics that lead to situation awareness and self-efficacy for each of the three careers. We found that four of our hypotheses were similar for all three occupations, but three of the hypotheses diverged. Flexibility had a positive effect on self-efficacy (H4), which was true for all. Self-esteem (H6) and altruism (H7) both had 
a positive effect on self-efficacy. Altruism also had a positive effect for all to situation awareness (H3). These results were as expected, and the results conformed to expectations based on prior research (Allen \& Rushton, 1983; Giles et al., 2004; Philippe Rushton, Chrisjohn, \& Cynthia Fekken, 1981; Smith et al., 1983).

Where the fire fighters and law enforcement and military diverged was in flexibility to situation awareness (H1), Self-esteem to situation awareness (H2) and self-sacrifice to self-efficacy (H5). For H1 and $\mathrm{H} 2$, we observed significant effects only for the military. For H5, self-sacrifice had a positive effect on self-efficacy, but only for the protection occupations, fire fighters and police.

Our ANOVA found that only situational awareness differed across the three groups, with military exhibiting the lowest levels of situational awareness. Police had more and firefighters had significantly higher situational awareness. See Figure 2 for the graph of situation awareness and occupation.

Lastly, our controls included age, education, gender and amount of in extremis experience that each individual had. The only significant path was age to self-efficacy $(\beta=-.05 \mathrm{p}=.022)$. This idea of with the wisdom of age perhaps comes the realization of one's own limits has also been found in other research (Woodward \& Wallston, 1987).

The final results are summarized in the Hypotheses Summary in Table 9.

TABLE 9

\section{HYPOTHESIS SUMMARY}

\begin{tabular}{|l|l|l|l|l|}
\hline & Hypotheses & $\begin{array}{l}\text { Evidence } \\
\text { Beta/P-value }\end{array}$ & $\begin{array}{l}\text { Supported } \\
\text { for all? }\end{array}$ & Occupations significant? \\
\hline H1 & $\begin{array}{l}\text { Flexibility will have a + effect on } \\
\text { SA }\end{array}$ & $-.102^{* *}$ & $\begin{array}{l}\text { Yes but } \\
\text { negative }\end{array}$ & Military only \\
\hline H2 & $\begin{array}{l}\text { Self-esteem will have a + effect } \\
\text { on SA }\end{array}$ & $.139 * * *$ & Yes & Military only \\
\hline H3 & $\begin{array}{l}\text { Altruism will have a + effect on } \\
\text { SA }\end{array}$ & $.583^{* * *}$ & Yes & All three \\
\hline H4 & $\begin{array}{l}\text { Flexibility will have a + effect on } \\
\text { SEFF }\end{array}$ & $.139^{* * *}$ & Yes & All three \\
\hline H5 & $\begin{array}{l}\text { Self-sacrifice will have a + effect } \\
\text { on SEFF }\end{array}$ & $.146^{* * *}$ & Yes & $\begin{array}{l}\text { Only fire fighters and law } \\
\text { enforcement }\end{array}$ \\
\hline H6 & $\begin{array}{l}\text { Self-esteem will have a + effect } \\
\text { on SEFF }\end{array}$ & $.578^{* * *}$ & Yes & All three \\
\hline H7 & $\begin{array}{l}\text { Altruism will have a + effect on } \\
\text { SEFF }\end{array}$ & $.236^{* * *}$ & Yes & All three \\
\hline
\end{tabular}

$* \mathrm{p}<0.05, * * \mathrm{p}<0.01, * * * \mathrm{p}<0.001$

\section{DISCUSSION}

Our research indicates that while in extremis contexts share many similarities, why an individual is in a hazardous condition is also a crucial element. We began this paper looking at the in extremis context as a whole, and we examined all our hypotheses looking at our respondents as one in extremis group. This was in keeping with most research on in extremis leadership, which focuses on the similarities of the in extremis groups (Kolditz, 2007; Sweeney et al., 2011); but our findings suggest that in extremis context is critical. Military, firefighters and law enforcement personnel all may routinely enter dangerous environments, but their jobs differ and the reasons they are in the in extremis situation make different leadership demands and may require distinct leadership skills.

There are contextual differences among the various occupations; lives are at stake in different ways. It is clear that these differences are initial explorations and more research is necessary to explore further. 
Although these occupations are often grouped together when classified by similarities (Kolditz, 2007; Sweeney et al., 2011), or divided by the environment (Campbell, 2012), variances in roles in in extremis conditions may cause confusion or ambiguity in leadership development and/or in training since firefighters and police are not always analogous to the military (Cowper, 2000; Lewis, 2013). The Bureau of Labor lists both law enforcement and firefighters as "protection services" (Pratt, 2013). Fire fighters' jobs are to protect the public by responding to fires and other emergencies; police protect lives and property (Statistics, 2013). While police officers may use deadly force, it should be used as a last resort. The military role in many operations is distinctly different; killing the enemy may be a viable objective.

Mission accomplishment is paramount in the military group, where as in the other two groups, loss of life has to be more closely weighed with mission accomplishment. A fire fighter faced with entering an empty burning building must assess whether saving part of the building is worth a life. The overall assessment would likely say no. Saving or protecting property is not as essential as saving and protecting lives. Law enforcement personnel face similar thought processes. Pursuing an armed felon who has stolen property may not be deemed to be an acceptable risk if there is no imminent danger to the civilian population. On the other hand, military leaders usually have an understanding of the risk of an operation, yet the loss of life may be deemed an acceptable outcome to accomplish the mission. Hence, the reason why a leader is acting and what they are trying to accomplish, as a protector or as a military member, is significant.

Although the in extremis label covers anyone facing death, this research illustrates there are differences even in the in extremis context; these differences are also manifested culturally. Traditionally, U.S. society looks at the fire fighters and law enforcement versus the military differently. Examining how member deaths are processed within the different occupations provides revealing evidence on the contextual differences between the military and the fire fighters and law enforcement. Historically, the U.S. public views deaths in the military as heroic (Bilu \& Witztum, 2000; Cole, 2005; Lacquement Jr, 1997), whereas deaths of fire fighters and law enforcement are usually seen as tragic (Bacon, 2013; Fonseca \& Dreier, 2013; Lowry, 2013; McGrail \& Rogers, 1993). Public opinion about the police deaths have begun to change, however, since the \#Blacklivesmatter movement (Krieger, Chen, Waterman, Kiang, \& Feldman, 2015); more research will have to be completed on this movement to see how police are viewed in the future.

Another societal difference between the emergency response occupations and the military includes unions. The military is not unionized, whereas fire fighters (IAFF, 2013) and police (Juris \& Feuille, 1973; Mas, 2006; Reiner, 1978) can be a part of a union. Union membership can lead loyalties to be with the union rather than to the boss or the company. For the military, unions are not sanctioned, and loyalty to the organization, the leadership and an individual's team are the principal driving forces.

We were surprised by the differences in situation awareness illustrated in Figure 5. Our initial thoughts were that the extensive training and leading-edge information systems provided for military personnel would mitigate the increased environmental uncertainty of combat operations and level the playing field in regard to situation awareness among the groups. Although we have not done in-depth study of the differences in situation awareness, our initial qualitative study and our past experiences lead us to some tentative explanations about the differences seen in Figure 2. First, combat operations tend to have much higher casualty rates than that of first responders and pose higher risk. Second, the geographic environment for military personnel tends to be less familiar than the more constrained geographic operating areas of first responders. Finally, the sheer number of potential threats is vastly greater for military operations. We feel that these combinations of factors tend to lead to less situation awareness for military personnel when confronted with in extremis environments. Likewise, the additional factor of hostile actors likely leads to less situation awareness for police officers when compared to firefighters. Further research would certainly be necessary to confirm these suppositions.

Also, unexpectedly in our results, flexibility negatively affects situation awareness; the inverse of what we expected. This was surprising since our interviewees from the earlier qualitative studycomprised of 30 combat veterans from Iraq and Afghanistan - described mental flexibility as a trait that would help a leader survive during in extremis situations. A typical comment on flexibility from a 
respondent in a qualitative interview summed up the thought. He said, "You have to be an adaptive thinker, flexible and agile to the point that if you get called, you can execute at any given point in time and not expect that every situation or every scenario can be trained on." Hence, we believed that flexibility would lead to more situation awareness for all occupations during in extremis conditions, but our data reveals the opposite. For the whole group, it was negative and when we separated out the specific jobs, only military was significant. Our supposition is that balance is the key. An individual needs some flexibility to be able to adjust from a plan, but perhaps too much flexibility could make it easier to lose focus and explore too many alternatives, this would have to be explored to get a fuller picture of what is actually occurring.

Our second hypothesis was that self-esteem has a positive effect on situation awareness. Again, although the effect was significant for the group as a whole, when tested with the careers as moderators, the effect held up only for military. For well over two decades, the United States has been involved in the conflicts in the Middle East. Individuals who join the military understand that there is a high probability that they will be entering into in extremis situations. Soldiers come to believe the risk is manageable and the cause is worthy; they are taught that situation awareness is vital to their existence, it becomes second nature. Additionally, as discussed earlier, firefighters and police operate in more constrained environments that may increase situation awareness independent of self-esteem. It also may be true that the military has spent much more money training situational awareness than firefighters or law enforcement personnel have the recourses to accomplish. This lack of training could also contribute to the lack of a significant, positive effect.

The final hypothesis, self-sacrifice had a positive effect on self-efficacy was not supported for military, but it was significant for both the law enforcement and fire fighters. Individuals who are drawn to the idea of protecting people and property, and the willingness to sacrifice themselves through public service, may feel that they are better able to accomplish tasks set before them. Although military are compelled to do their duty, they may not feel as though self-sacrifice is instrumental in accomplishing the mission. Sacrifice in the military tends to be in relation to serving their brothers and sisters in arms (i.e. an indirect mission). Sacrifice in first responders tends to be for serving the community in which the officer or firefighter lives and works (i.e. the direct mission).

Our work emphasizes that leaders facing serious personal danger are alike in some ways; however, examining the differences as to why an individual is in the in extremis situation is crucial. Is the leader there to protect or for a military mission? Situational leadership implies there are no consistent factors in any leadership situation and even if you have similarity among in extremis categories, the leadership will still be different because, to be effective, the leader has to adapt his/her style to each situation (Bass \& Bass, 2008).

It is beyond the scope of this paper to postulate how training or hiring may be changed due to these differences among these occupations, but our results do suggest that the four characteristics of flexibility, altruism, self-sacrifice and self-esteem may lead to increases in both situation awareness and selfefficacy. It is, therefore, logical to assume that during in extremis situations these factors may help increase positive outcomes for all three groups. More research needs to be done on all three of these groups, focusing on their similarities and their differences.

\section{LIMITATIONS}

As always, there are limitations to our study. The most significant limitation is the result of the selfreport survey. Although some of the constructs would have been better to observe behaviorally, due to the complexity of observations during in extremis environments, all of our data were collected through selfreport processes. We acknowledge that we are relying on participants to remember the details of the in extremis situation unambiguously as well as their feelings at that time. Even though we asked them to keep in mind a specific in extremis situation while filling out the survey, it is not known if they did. Although people are capable of having clarity over stressful incidents (Christianson, 1992), there can still be issues regarding memory fidelity and social desirability. 
As another limitation, social desirability often affects self-report studies; the concern is that individuals may contaminate the data by trying to present themselves favorably (Edwards, 1957; R. J. Fisher, 1993; Grimm, 2010). Our study is comprised of senior leaders who are drawn to helping others as a career, and seem to be more intrinsically motivated, than driven by extrinsic rewards (Thomas \& Jansen, 1996). We relied on the respondents to complete our survey truthfully.

These constructs are also all psychological, leaders have these thoughts in a nano second. During in extremis situations they don't really spend time thinking about them. More research needs to be completed seeing if these can be replicated in another sample.

There is certainly a duty limitation to our research. Obviously, all of the leaders participating in our research survived there in extremis encounters. Examining encounters where the leader perished would require surveying team members about a leader's performance ex post. While possible, this would be an extremely difficult undertaking.

Finally, our study is U.S. based. Although our survey did garner a few international responses the data were sparse, so this study is U.S. focused only. Other cultures may have different outcomes.

Our study was restricted to occupations of service in in extremis contexts - military, firefighters and law enforcement personnel. While this homogeneity helped the theoretical development of this exploratory research, it is not clear whether our data is representative of leaders in other in extremis environments like mountain climbers or sky diving teams; the culture of the occupation may play a role (Probert \& Turnbull James, 2011).

\section{IMPLICATIONS FOR PRACTICE AND FUTURE RESEARCH}

There have been several studies examining military and fire fighters, or police and firefighters, or even military and law enforcement; emergency management technicians are occasionally thrown into the research also. Most of these studies have focused on the similarities of these in extremis groups. To our knowledge, this is the first study focusing on all three in in extremis conditions to look at their differences with situation awareness and self-efficacy. Our findings indicate that, although the groups are invariant and can be studied together, there are differences among the occupations that cannot be ignored, and the roles of both situation awareness and self-efficacy are paramount.

Discovering some of the antecedents for situation awareness and self-efficacy is a daunting task, and we have only scratched the surface. Measuring situational awareness behaviorally would be another good initiative. The four human variables that we chose were derived from the qualitative interviews of Army personnel. Our data suggests that these four characteristics are important, but perhaps there are others, more essential for fire fighters and law enforcement personnel. Today's changing environments make it difficult to predict what will be important in the future.

Our results point to the need for substantially more empirical research about situation awareness and self-efficacy and their antecedents in in extremis environments. Future research should also investigate the disparate roles of hazardous occupations in in extremis environments. Of particular interest may be the in extremis dynamic of modern business executives. Research that benefits in extremis leaders can potentially be sources to enhance the effectiveness of other types of leaders. Although individuals in business may not be facing personal death, they are often in situations that could mean death to their organizations or the livelihood of their employees. Losing big accounts, stocks/markets collapsing, or situations where an individual may lose the capacity to reason and cannot see "the way out" can lead to catastrophic assessments and decisions. Reports of suicide were rife after the various crashes on wall street $(1929,1987,2008)$ because people thought their situations were cataclysmic (Altucher, 2010; Rothbard, 1972). Learning to deal with these stressful situations may be beneficial to others besides those facing actual death. Examining what makes individuals successful during ambiguous, uncertain times could be advantageous to a myriad of occupations. 


\section{REFERENCES}

Allen, N. J., \& Rushton, J. P. (1983). Personality characteristics of community mental health volunteers: A review. Nonprofit and Voluntary Sector Quarterly, 12(1), 36-49.

Altucher, J. (2010). Wall Street suicide. CNBC. Retrieved from https://www.cnbc.com/id/40841645

Army Human Resources Command. (2017). Washington D.C.: US Army. Retrieved from https://www.hrc.army.mil/

Artman, H., \& Garbis, C. (1998). Situation awareness as distributed cognition. Paper presented at the 9th European Conference on Cognitive Ergonomics (ECCE), University of Limerick, Limerick, Ireland.

Baard, S. K., Rench, T. A., \& Kozlowski, S. W. (2014). Performance adaptation: A theoretical integration and review. Journal of Management, 40(1), 48-99.

Bacon, J. (2013). Hofstra community shocked by tragic police shooting. USA Today Retrieved from http://www.usatoday.com/story/news/nation/2013/05/19/hofstra-student-killed-by-police-duringbreak-in/2323831/

Bandura, A. (1982). Self efficacy mechanism in human agency. American Psychologist, 37(2), 122-147.

Bandura, A. (1997). Self-efficacy: The exercise of control. Worth Publishers.

Bandura, A., \& Locke, E. A. (2003). Negative self-efficacy and goal effects revisited. Journal of Applied Psychology, 88(1), 87.

Bar-On, R. (1996). BarOn Emotional Quotient Inventory.

Bar-On, R. (1997). The emotional quotient inventory (EQ-i). Technical Manual. Toronto Multi Health Systems.

Bar-On, R., \& Parker, J. (Eds.). (2000). The handbook of emotional intelligence: Theory, development, assessment, and application at home, school and in the workplace. San Franscisco: Jossey-Bass.

Baran, B., \& Scott, C. (2010). Organizing ambiguity: A grounded theory of leadership and sensemaking within dangerous contexts. Military Psychology, 22, 42-69.

Bass, B., \& Bass, R. (2008). The Bass handbook of leadership: Theory, research, and managerial applications: Free Press.

Baumeister, R. F., Campbell, J. D., Krueger, J. I., \& Vohs, K. D. (2003). Does high self-esteem cause better performance, interpersonal success, happiness, or healthier lifestyles? Psychological science in the public interest, 4(1), 1-44.

Baumeister, R. F., Tice, D. M., \& Hutton, D. G. (1989). Self-presentational motivations and personality differences in self-esteem. Journal of Personality, 57(2), 547-579.

Bechky, B. A., \& Okhuysen, G. A. (2011). Expecting the unexpected? How SWAT officers and film crews handle surprises. Academy of management Journal, 54(2), 239-261.

Bilu, Y., \& Witztum, E. (2000). War-related loss and suffering in Israeli society: An historical perspective. Israel Studies, 5(2), 1-31.

Bolton, R. N. (1993). Pretesting questionnaires: Content analyses of respondents' concurrent verbal protocols. Marketing Science, 12(3), 280-303.

Bono, J. E., \& Judge, T. A. (2003). Core self-evaluations: A review of the trait and its role in job satisfaction and job performance. European Journal of Personality, 17(S1), S5-S18.

Brockner, J. (1988). Self-esteem at work: Research, theory, and practice: Lexington Books/DC Heath and Com.

Campbell, D. J. (2012). Leadership in dangerous contexts: A team-focused, replenishment-of-resources approach. In J. H. Laurence \& M. Matthews (Eds.), The Oxford Handbook of Military Psychology (pp. 158-173). New York: Oxford University Press.

Campbell, D. J., Hannah, S., \& Matthews, M. (2010). Leadership in military and other dangerous contexts: Introduction to the special topic issue. Military Psychology, 22, 1-14.

Chemers, M. M., \& Ayman, R. E. (1993). Leadership theory and research: Perspectives and directions: Academic Press. 
Chemers, M. M., Watson, C. B., \& May, S. T. (2000). Dispositional affect and leadership effectiveness: A comparison of self-esteem, optimism, and efficacy. Personality and Social Psychology Bulletin, 26(3), 267-277.

Chen, G., Gully, S. M., \& Eden, D. (2001). Validation of a new general self-efficacy scale. Organizational Research Methods, 4(1), 62.

Christianson, S. Å. (1992). Emotional stress and eyewitness memory: A critical review. Psychological bulletin, 112(2), 284.

Cole, T. (2005). The political rhetoric of sacrifice and heroism and US Military intervention. In Y. R. Kamalipour \& L. Artz (Eds.), Bring 'em on: Media and politics in the Iraq War (pp. 139-154). Lanham, MD: Rowman \& Littlefield Publishers.

Cooper, R. K., \& Sawaf, A. (1998). Executive EQ: Emotional intelligence in leadership and organizations: Penguin.

Copeland, T. (1998). How much is flexibility worth? The McKinsey Quarterly(2), 38-49.

Corbin, J. M., \& Strauss, A. L. (2008). Basics of qualitative research: Techniques and procedures for developing grounded theory (3rd ed.). Thousand Oaks, CA: Sage Publications, Inc.

Cowper, T. J. (2000). The myth of the "military model" of leadership in law enforcement. Police Quarterly, 3(3), 228-246.

Cremer, D. D., \& Knippenberg, D. v. (2004). Leader self-sacrifice and leadership effectiveness: The moderating role of leader self-confidence. Organizational behavior and human decision processes, 95(2), 140-155.

Dixon, D. P., Weeks, M., Boland Jr, R., \& Perelli, S. (2016). Making sense when it matters most: An exploratory study of leadership in extremis. Journal of Leadership \& Organizational Studies, 24(3), 294-317.

Dow, M., Garis, F. C. L., \& Thomas, D. C. L. (2013). Reframing situational awareness within the fire service culture: University of the Fraser Valley.

Edwards, A. L. (1957). The social desirability variable in personality assessment and research.

Endsley, M. R. (1995a). Measurement of situation awareness in dynamic systems. Human Factors: The Journal of the Human Factors and Ergonomics Society, 37(1), 65-84.

Endsley, M. R. (1995b). Toward a theory of situation awareness in dynamic systems. Human Factors: The Journal of the Human Factors and Ergonomics Society, 37(1), 32-64.

Endsley, M. R., \& Garland, D. J. (Eds.). (2000). Situation awareness: Analysis and measurement: CRC.

Ericsson, K. A., Charness, N., Feltovich, P. J., \& Hoffman, R. R. (2006). The Cambridge handbook of expertise and expert performance. Cambridge University Press.

Ericsson, K. A., Krampe, R. T., \& Tesch-Römer, C. (1993). The role of deliberate practice in the acquisition of expert performance. Psychological review, 100(3), 363.

Feltz, D. L., \& Weiss, M. R. (1982). Developing self-efficacy through sport. Journal of Physical Education, Recreation \& Dance, 53(3), 24-26, 36.

Fernandez, R., Vozenilek, J. A., Hegarty, C. B., Motola, I., Reznek, M., Phrampus, P. E., \& Kozlowski, S. W. (2008). Developing expert medical teams: Toward an evidence-based approach. Academic Emergency Medicine, 15(11), 1025-1036.

Fiedler, F. (1993). The leadership situation and the black box in contingency theories (pp. Paper presented at the Annual Claremont McKenna College Leadership Conference: "The Future of Leadership Research: A Tribute to Fred Fiedler", 4th, Feb, 1991, Claremont McKenna Coll, Claremont, CA, US.

Fisher, K., \& Robbins, C. R. (2015). Embodied leadership: Moving from leader competencies to leaderful practices. Leadership, 11(3), 281-299. doi:10.1177/1742715014522680

Fisher, R. J. (1993). Social desirability bias and the validity of indirect questioning. Journal of consumer research, 303-315.

Fonseca, F., \& Dreier, H. (2013). Arizonia Wildfire 2013: 19 firefighters die while battling Yarnell Hill Blaze. Huffington Post. Retrieved from http://www.huffingtonpost.com/2013/06/30/arizonawildfire-yarnell_n_3526934.html

54 American Journal of Management Vol. 19(3) 2019 
Fraher, A. L., Branicki, L. J., \& Grint, K. (2017). Mindfulness in action: Discovering how US Navy SEALs build capacity for mindfulness in high-reliability organizations (HROs). Academy of Management Discoveries, 3(3), 239-261.

Ganster, D. C., \& Shaubroeck, J. (1991). Role stress and worker health: An extension of the plasticity hypothesis of self-esteem. Journal of Social Behavior \& Personality, 6(7), 349.

Gasaway, R. B. (2007). Making intuitive decisions under stress: Understanding fireground incident command decision-making. International fire service journal of leadership and management, $1(1), 8-18$.

Gecas, V. (1989). The social psychology of self-efficacy. Annual review of sociology, 291-316.

Geier, M. T. (2016). Leadership in extreme contexts transformational leadership, performance beyond expectations? Journal of Leadership \& Organizational Studies, 23(3), 234-247.

Giles, M., McClenahan, C., Cairns, E., \& Mallet, J. (2004). An application of the theory of planned behaviour to blood donation: The importance of self-efficacy. Health Education Research, 19(4), 380-391.

Goldsmith, S., \& Eggers, W. D. (2004). Governing by network: The new shape of the public sector. Brookings Institution Press.

Graen, G., \& Graen, J. (Eds.). (2013). Management of team leadership in extreme context: Defending our homeland, protecting our first responders (LMX leadership). Charlotte, NC: Information Age Publishing, Inc.

Grimm, P. (2010). Social desirability bias Wiley International Encyclopedia of Marketing. John Wiley \& Sons, Ltd.

Groysberg, B., Hill, A., \& Johnson, T. (2010). Which of these people is your future CEO? Harvard Business Review, 88(11), 80-85.

Guilford, J. P. (1954). Psychometric methods (2nd ed.). New York, NY: McGraw-Hill.

Hair, J. F., Black, W. C., Babin, B. J., \& Anderson, R. E. (2010). Multivariate data analysis (7th ed.). Upper Saddle River, NJ: Pearson Prentice Hall

Hannah, S. T. (2006). Agentic leadership efficacy: Test of a new construct and model for development and performance. ProQuest Information \& Learning.

Hannah, S. T., Jennings, P. L., Bluhm, D., Peng, A. C., \& Schaubroeck, J. M. (2014). Duty orientation: Theoretical development and preliminary construct testing. Organizational behavior and human decision processes, 123(2), 220-238.

Hannah, S. T., \& Lester, P. B. (2009). A multilevel approach to building and leading learning organizations. The Leadership Quarterly, 20(1), 34-48.

Hannah, S. T., Uhl-Bien, M., Avolio, B. J., \& Cavarretta, F. L. (2009). A framework for examining leadership in extreme contexts. The Leadership Quarterly, 20(6), 897-919.

Hersey, P., \& Blanchard, K. H. (1969). Management of organizational behavior: Prentice-Hall Englewood Cliffs, NJ.

Holden, G. (1992). The relationship of self-efficacy appraisals to subsequent health related outcomes: A meta-analysis. Social work in health care, 16(1), 53-93.

Holden, G., Meenaghan, T., Anastas, J., \& Metrey, G. (2002). Outcomes of social work education: The case for social work self-efficacy. Journal of Social Work Education, 115-133.

House, R. J., \& Aditya, R. N. (1997). The social scientific study of leadership: quo vadis? Journal of Management, 23(3), 409-473.

Hytten, K., \& Hasle, A. (1989). Fire fighters: A study of stress and coping. Acta Psychiatrica Scandinavica, 80, 50-55.

IAFF. (2013). International Association of FireFighters. Retrieved from http://www.iaff.org/

Jarvis, C. B., MacKenzie, S. B., \& Podsakoff, P. M. (2003). A critical review of construct indicators and measurement model misspecification in marketing and consumer research. Journal of consumer research, 30(2), 199-218. 
Jensen, E., \& Brehmer, B. (2005). Sensemaking in the fog of war: An experimental study of how command teams arrive at a basis for action (pp. 14). Swedish National Defence College Stockholm Dept of War Studies: Citeseer.

Johnson, W. B., Johnson, S. J., Sullivan, G. R., Bongar, B., Miller, L., \& Sammons, M. T. (2011). Psychology in extremis: Preventing problems of professional competence in dangerous practice settings. Professional Psychology: Research and Practice, 42(1), 94.

Judge, T. A., \& Bono, J. E. (2001). Relationship of core self-evaluations traits-self-esteem, generalized self-efficacy, locus of control, and emotional stability - with job satisfaction and job performance: A meta-analysis. Journal of Applied Psychology, 86(1), 80.

Juris, H. A., \& Feuille, P. (1973). Police unionism: Power and impact in public-sector bargaining. Massachusetts: Lexington Books

Klein, G. A., Calderwood, R., \& Clinton-Cirocco, A. (1986). Rapid decision making on the fire ground (pp. 576-580). Paper presented at the Proceedings of the Human Factors and Ergonomics Society annual meeting.

Klein, K., Ziegert, J., Knight, A., \& Xiao, Y. (2006). Dynamic delegation: Shared, hierarchical, and deindividualized leadership in extreme action teams. Administrative Science Quarterly, 51(4), 590-621.

Kohn, M. (1989). Class and conformity: A study in values: University of Chicago Press.

Kolditz, T. A. (2006). Research in in extremis settings. Armed Forces \& Society, 32(4), 655-658.

Kolditz, T. A. (2007). In extremis leadership (1st ed.). San Francisco, CA: Jossey-Bass.

Kozlowski, W., Gully, S., Salas, E., \& Cannon-Bowers, J. (1996). Team leadership and development: Theory, principles, and guidelines for training leaders and teams.

Krieger, N., Chen, J. T., Waterman, P. D., Kiang, M. V., \& Feldman, J. (2015). Police killings and police deaths are public health data and can be counted. PLoS Med, 12(12), e1001915.

Lacquement Jr, R. A. (1997). The casualty-aversion myth. Retrieved from

Laurence, J. H., \& Matthews, M. D. (2012). The Oxford Handbook of Military Psychology. Oxford University Press, USA.

Lent, R. W., Sheu, H.-B., Singley, D., Schmidt, J. A., Schmidt, L. C., \& Gloster, C. S. (2008).

Longitudinal relations of self-efficacy to outcome expectations, interests, and major choice goals in engineering students. Journal of Vocational Behavior, 73(2), 328-335.

Lewis, A. (2013). Mindfulness, self-compassion, and leadership in wildland firefighting.

Locke, E. A. (1999). The essence of leadership: The four keys to leading successfully. Lexington Books.

Lowry, N. (2013). Tragic day: DA reflects on death of Shenango police officer. New Castle News Retrieved from http://www.ncnewsonline.com/topstories/x319977300/-Tragic-day-DA-reflectson-death-of-Shenango-police-officer

Marsh, H. W. (1990). A multidimensional, hierarchical model of self-concept: Theoretical and empirical justification. Educational Psychology Review, 2(2), 77-172.

Martin, M. M., \& Anderson, C. M. (1998). The cognitive flexibility scale: Three validity studies. Communication Reports, 11(1), 1-9.

Martin, M. M., \& Rubin, R. B. (1995). A new measure of cognitive flexibility. Psychological reports, 76(2), 623-626.

Mas, A. (2006). Pay, reference points, and police performance. The Quarterly Journal of Economics, 121(3), 783-821.

Mathieu, J. E., \& Taylor, S. R. (2006). Clarifying conditions and decision points for mediational type inferences in organizational behavior. Journal of Organizational Behavior, 27(8), 1031-1056.

Matthews, M. D. (2012). Cognitive and Non-Cognitive Factors in Soldier Performance. The Oxford Handbook of Military Psychology, 197.

Matthews, M. D. (2014). Head Strong: How Psychology is Revolutionizing War. New York: Oxford University Press.

McGrail, D., \& Rogers, J. (1993). Confined space claims Denver firefighter in a tragic building fire. FIRE ENGINEERING, 146, 59-59. 
Mertler, C. A., \& Vannatta, R. A. (2005). Advanced and multivariate statistical methods: Practical application and interpretation. Pyrczak.

Miner, J. B. (2002). Organizational behavior: Foundations, theories, and analyses: Oxford University Press, USA.

Moritz, S. E., Feltz, D. L., Fahrbach, K. R., \& Mack, D. E. (2000). The relation of self-efficacy measures to sport performance: A meta-analytic review. Research Quarterly for Exercise and Sport, 71(3), 280-294.

Multon, K. D., Brown, S. D., \& Lent, R. W. (1991). Relation of self-efficacy beliefs to academic outcomes: A meta-analytic investigation. Journal of counseling psychology, 38(1), 30.

Murphy, M. J. (1965). Problem of compliance by police departments. Texas Law Review, 44, 939.

Northouse, P. G. (2013). Leadership: Theory and practice (6th ed.). Thousand Oaks: Sage.

Paglis, L. L., \& Green, S. G. (2002). Leadership self-efficacy and managers' motivation for leading change. Journal of Organizational Behavior, 23(2), 215-235.

Palmer, N., Hannah, S. T., \& Sosnowik, D. (2011). Leader development for dangerous contexts. In P. J. Sweeney, M. D. Matthews, \& P. B. Lester (Eds.), Leadership in dangerous situations: A handbook for the armed forces, emergency services, and first responders (pp. 350-372). Annapolis: Naval Institue Press in conjuction with Association of the United States Army (AUSA).

Perry, J. L. (1996). Measuring public service motivation: An assessment of construct reliability and validity. Journal of public administration research and theory, 6(1), 5-22.

Philippe Rushton, J., Chrisjohn, R. D., \& Cynthia Fekken, G. (1981). The altruistic personality and the self-report altruism scale. Personality and individual differences, 2(4), 293-302.

Pierce, J. L., \& Gardner, D. G. (2004). Self-esteem within the work and organizational context: A review of the organization-based self-esteem literature. Journal of Management, 30(5), 591-622.

Podsakoff, P. M., MacKenzie, S. B., Lee, J. Y., \& Podsakoff, N. P. (2003). Common method biases in behavioral research: a critical review of the literature and recommended remedies. Journal of Applied Psychology, 88(5), 879.

Pratt, M. (2013). Trust under Fire: The Social Construction of Trustworthiness amongst Firefighters. Boston College.

Probert, J., \& Turnbull James, K. (2011). Leadership development: Crisis, opportunities and the leadership concept. Leadership, 7(2), 137.

Ramthun, A. J., \& Matkin, G. S. (2014). Leading dangerously a case study of military teams and shared leadership in dangerous environments. Journal of Leadership \& Organizational Studies, 21(3), 244-256.

Reiner, R. (1978). The Blue-Coated Worker: A sociological study of police unionism: Cambridge University Press Cambridge.

Robinson, J. P., Wrightsman, L. S., \& Andrews, F. M. (1991). Measures of personality and social psychological attitudes (Vol. 1): Academic Pr.

Rosenberg, M. (1965). Society and the adolescent self image. Princeton, NJ: Princeton University Press.

Rothbard, M. (1972). America's Great Depression. Ludwig von Mises Institute.

Sadri, G., \& Robertson, I. T. (1993). Self-efficacy and Work-related Behaviour: A Review and Metaanalysis. Applied Psychology, 42(2), 139-152.

Saks, A. M. (1995). Longitudinal field investigation of the moderating and mediating effects of selfefficacy on the relationship between training and newcomer adjustment. Journal of Applied Psychology, 80(2), 211.

Salas, E., Prince, C., Baker, D. P., \& Shrestha, L. (1995). Situation awareness in team performance: Implications for measurement and training. Human Factors: The Journal of the Human Factors and Ergonomics Society, 37(1), 123-136.

Salmon, P., Stanton, N., Walker, G., \& Green, D. (2006). Situation awareness measurement: A review of applicability for C4i environments. Applied ergonomics, 37(2), 225-238. 
Scarnati, J. T. (1999). Beyond technical competence: the fundamentals of flexibility. Participation and Empowerment: An International Journal, 7(7), 194-200.

Shusta, R. M., Levine, D. R., Harris, P. R., \& Wong, H. Z. (2002). Multicultural law enforcement: Strategies for peacekeeping in a diverse society: Prentice Hall Upper Saddle River, NJ.

Sisk, R. (2015). Women in combat: Silver Stars, CAB and casulaties. Retrieved from http://www.military.com/daily-news/2015/08/31/women-in-combat-silver-stars-combat-actionbadges-casualties.html

Smith, C., Organ, D. W., \& Near, J. P. (1983). Organizational citizenship behavior: Its nature and antecedents. Journal of Applied Psychology; Journal of Applied Psychology, 68(4), 653-663.

Stajkovic, A. D., \& Luthans, F. (1998). Self-efficacy and work-related performance: A meta-analysis. Psychological bulletin, 124(2), 240.

Statistics, B. o. L. (2013). Occupational outlook handbook. Retrieved from http://www.bls.gov/ooh/protective-service/firefighters.htm\#tab-1

Strater, L., Endsley, M., Pleban, R., Matthews, M., \& TRW Inc Fairfax VA Systems Information Technology Group. (2001). Measures of platoon leader situation awareness in virtual decisionmaking exercises. US Army Research Institute for the Behavioral and Social Sciences.

Suhr, D. D., \& Colorado, U. o. N. (2006). Exploratory or confirmatory factor analysis? : SAS Institute Cary.

Sweeney, P., Matthews, M., \& Lester, P. (2011). Leadership in dangerous situations: A handbook for the armed forces, emergency services, and first responders. Annapolis, MD: US Naval Institute Press.

Taylor, R. (1990). Situational awareness rating technique (SART): The development of a tool for aircrew systems design (pp. Paper presented at the the Situational Awareness in Aerospace Operations AGARDCP478.

Thomas, K., \& Jansen, E. (1996). Intrinsic Motivation in the Military: Models and Strategic Importance.

Truckenbrodt, Y. B. (2000). The relationship between leader-member exchange and commitment and organizational citizenship behavior. Acquisition Review Quarterly, 7(3), 233.

van den Berg, C., \& Soeters, J. (2009). Self-perceptions of soldiers under threat: A field study of the influence of death threat on soldiers. Military Psychology, 21, 2.

Van Knippenberg, B., \& Van Knippenberg, D. (2005). Leader self-sacrifice and leadership effectiveness: the moderating role of leader prototypicality. Journal of Applied Psychology, 90(1), 25.

Vroom, V. H., \& Jago, A. G. (1995). Situation effects and levels of analysis in the study of leader participation. The Leadership Quarterly, 6(2), 169-181.

Vroom, V. H., \& Yetton, P. W. (1973). Leadership and decision-making: University of Pittsburgh Pre.

Watters, B. S. (2017). Leadership in the 'Wicked'Problem of Bosnia's civil war: A case study examining ethical decision making under duress. Leadership, 1742715017725641.

Waugh, W. L., \& Streib, G. (2006). Collaboration and leadership for effective emergency management. Public Administration Review, 66(s1), 131-140.

Weick, K. (1993). The collapse of sensemaking in organizations: The Mann Gulch disaster. Administrative Science Quarterly, 38(4), 628-652.

Wellens, A. R. (1993). Group situation awareness and distributed decision making: From military to civilian applications. Individual and group decision making: Current issues, 267-287.

Wong, L., Kolditz, T., Millen, R., \& Potter, T. (2003). Why they fight: Combat motivation in the Iraq war: Strategic Studies Institute, US Army War College.

Woodward, N. J., \& Wallston, B. S. (1987). Age and Health Care Beliefs. Psychology and Aging, 2(1), 38. doi:10.1037/0882-7974.2.1.3

Yukl, G. (2002). Leadership in organizations (5th ed.). Upper Saddle River: Prentice-Hall, Inc.

Yukl, G. A., \& Van Fleet, D. D. (1982). Cross-situational, multimethod research on military leader effectiveness. Organizational Behavior and Human Performance, 30(1), 87-108. 


\section{APPENDICES}

\section{APPENDIX A SUMMARY OF ORIGINAL MEASURES}

\begin{tabular}{|c|c|c|c|}
\hline Construct & Definition & Items & Source \\
\hline Self-Efficacy & $\begin{array}{l}\text { Belief in personal } \\
\text { capabilities to } \\
\text { mobilize the } \\
\text { motivation, } \\
\text { resources, and } \\
\text { courses of action } \\
\text { needed to meet } \\
\text { given situation. }\end{array}$ & $\begin{array}{l}\text { Five-point Likert scale: Strongly disagree to } \\
\text { strongly agree } \\
\text { 1. I will be able to achieve most of the } \\
\text { goals that I have set for myself.** } \\
\text { 2. When facing difficult tasks, I am } \\
\text { certain that I will accomplish them.* } \\
\text { 3. In general, I think that I can obtain } \\
\text { outcomes that are important to me.** } \\
\text { 4. I believe I can succeed at most any } \\
\text { endeavor to which I set my mind. } \\
\text { 5. I will be able to successfully overcome } \\
\text { many challenges. } \\
\text { 6. I am confident that I can perform } \\
\text { effectively on many different tasks** } \\
\text { 7. Compared to other people, I can do } \\
\text { most tasks very well* } \\
\text { 8. Even when things are tough, I can } \\
\text { perform quite well. }\end{array}$ & $\begin{array}{l}\text { Adapted from the } \\
\text { New General Self } \\
\text { Efficacy Scale by } \\
\text { Chen et al. (2001) }\end{array}$ \\
\hline Situation Awareness & $\begin{array}{l}\text { Being aware of what } \\
\text { is happening in the } \\
\text { vicinity to } \\
\text { understand how } \\
\text { information, events, } \\
\text { and one's own } \\
\text { actions will impact } \\
\text { goals and objectives. }\end{array}$ & $\begin{array}{l}\text { Five-point Likert scale: Strongly disagree to } \\
\text { strongly agree } \\
\text { 1. It was likely that the situation could } \\
\text { change suddenly** } \\
\text { 2. There were many variables that } \\
\text { required my attention. } \\
\text { 3. The situation at the time was } \\
\text { complex.** } \\
\text { 4. I was ready for the activity.* } \\
\text { 5. I was overwhelmed by all the new } \\
\text { things I had to think about.* } \\
\text { 6. I was very focused on what was going } \\
\text { on.** } \\
\text { 7. There were several different things I } \\
\text { had to focus on during this situation. }\end{array}$ & $\begin{array}{l}\text { These questions } \\
\text { were developed } \\
\text { from the SART } \\
\text { definition of SA } \\
\text { (Endsley \& } \\
\text { Garland, 2000, p. } \\
\text { 118) }\end{array}$ \\
\hline Flexibility & $\begin{array}{l}\text { Ability of } \\
\text { respondents to } \\
\text { adjust their } \\
\text { emotions, thoughts } \\
\text { and behaviors to } \\
\text { changing situations } \\
\text { and conditions }\end{array}$ & $\begin{array}{l}\text { Five-point Likert scale: Strongly disagree to } \\
\text { strongly agree } \\
\text { 1. It's easy for me to begin new things.** } \\
\text { 2. It's easy for me to make adjustments in } \\
\text { general. } \\
\text { 3. It's easy for me to change my opinion } \\
\text { about things.** } \\
\text { 4. It's easy for me to adjust to new } \\
\text { conditions easily. } \\
\text { 5. I'm able to change old habits.** } \\
\text { 6. It's generally easy for me to make } \\
\text { changes in my daily life. } \\
\text { 7. It's easy for me to change my ways.** } \\
\text { 8. It would be easy for me to adjust if I } \\
\text { were forced to leave my home.** }\end{array}$ & $\begin{array}{l}\text { Adapted from Bar- } \\
\text { On EQI (1997) }\end{array}$ \\
\hline
\end{tabular}




\begin{tabular}{|c|c|c|c|}
\hline Altruism & $\begin{array}{l}\text { Willingness to be } \\
\text { helpful to others }\end{array}$ & $\begin{array}{l}\text { Five-point Likert scale: Strongly disagree to } \\
\text { strongly agree } \\
\text { It's just like me to: } \\
\text { 1. Help push a stranger's car out of the } \\
\text { snow. } \\
\text { 2. Give directions to a stranger. } \\
\text { 3. Donate goods or clothes to a charity.** } \\
\text { 4. Do volunteer work for a charity.** } \\
\text { 5. Point out a clerk's error when the error } \\
\text { was in my favor.** } \\
\text { 6. Help someone (not a friend) with a task } \\
\text { when my ability/knowledge was great } \\
\text { than his/hers. } \\
\text { 7. Give up my seat to a stranger who was } \\
\text { standing.** } \\
\text { 8. Help an acquaintance to move } \\
\text { households. ** }\end{array}$ & $\begin{array}{l}\text { Adapted from } \\
\text { Smith et al. (1983) }\end{array}$ \\
\hline Self-Sacrifice & $\begin{array}{l}\text { Focuses on your } \\
\text { willingness to } \\
\text { sacrifice yourself for } \\
\text { public service }\end{array}$ & $\begin{array}{l}\text { Five-point Likert scale: Strongly disagree to } \\
\text { strongly agree } \\
\text { 1. Making a difference in society means } \\
\text { more to me than personal } \\
\text { achievements. } \\
\text { 2. I believe in putting duty before self. } \\
\text { 3. Doing well financially is definitely } \\
\text { more important to me than doing good } \\
\text { deeds.** }\end{array}$ & $\begin{array}{l}\text { Adapted from } \\
\text { Altruism scale } \\
\text { Perry (1996) }\end{array}$ \\
\hline Self Esteem & $\begin{array}{l}\text { Original scale: } \\
\text { Response } 0=\text { No } \\
\text { Answer Response } 1 \\
=\text { not true } \\
\text { Response } 2= \\
\text { Seldom true } \\
\text { Response } \\
3=\text { Sometimes true } \\
\text { Response } 4=\text { Often } \\
\text { true Response } 5= \\
\text { Very Often true }\end{array}$ & $\begin{array}{l}\text { Five-point Likert scale: Strongly disagree to } \\
\text { strongly agree } \\
\text { 1. I feel like I am a person of worth. } \\
\text { 2. All in all, I am inclined to feel that I am } \\
\text { a failure.** } \\
\text { 3. I am able to do things as well as most } \\
\text { people.** } \\
\text { 4. I feel I do not have much to be proud } \\
\text { of. ** } \\
\text { 5. I take a positive attitude toward myself. } \\
\text { 6. On the whole, I am satisfied with } \\
\text { myself. }\end{array}$ & $\begin{array}{l}\text { Adapted from Self- } \\
\text { Esteem Scale } \\
\text { Rosenberg (1965) }\end{array}$ \\
\hline $\begin{array}{l}\text { Frequency of IE } \\
\text { Experience }\end{array}$ & $\begin{array}{l}\text { Experience of being } \\
\text { deployed in a } \\
\text { dangerous situation. }\end{array}$ & $\begin{array}{l}\text { Prior to your last dangerous environment, } \\
\text { how many times had you been deployed to a } \\
\text { combat zone or been placed in a dangerous } \\
\text { environment? This was my first } \\
\text { deployment; } 1 \text { or two others; } 3 \text { or } 4 \\
\text { deployments; } 5 \text { deployments; Over six } \\
\text { deployments }\end{array}$ & $\begin{array}{l}\text { Developed for this } \\
\text { paper }\end{array}$ \\
\hline
\end{tabular}

*Deleted based on pretest respondents ** Deleted to improve validity and reliability 


\section{APPENDIX B}

CFA

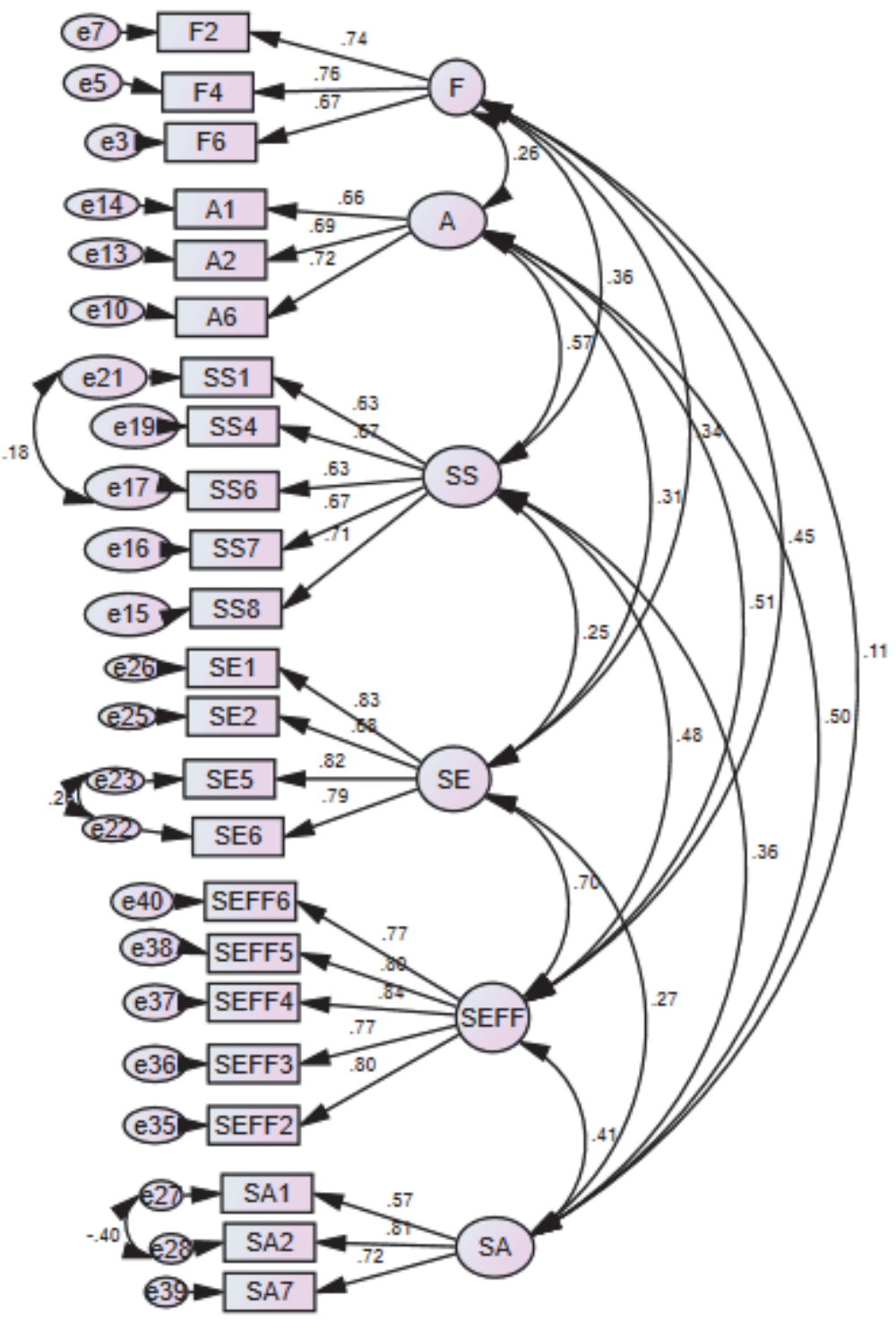




\section{APPENDIX C \\ MODEL FIT AND OCCUPATION SEM}

TABLE C1

MEASUREMENT MODEL FIT

\begin{tabular}{|l|l|}
\hline Measure & $\begin{array}{l}\text { Our model } \\
\text { tested }\end{array}$ \\
\hline $\begin{array}{l}\text { Chi-square/df } \\
\text { (cmin/df) }\end{array}$ & $\begin{array}{l}323.501 / 212 \\
1.526\end{array}$ \\
\hline $\begin{array}{l}\text { P value for the } \\
\text { model }\end{array}$ & .000 \\
\hline CFI & .977 \\
\hline GFI & .948 \\
\hline AGFI & .932 \\
\hline SRMR & .0372 \\
\hline RMSEA & .032 \\
\hline NFI & .937 \\
\hline PCLOSE & 1 \\
\hline
\end{tabular}

FIGURE C1 MILITARY SEM

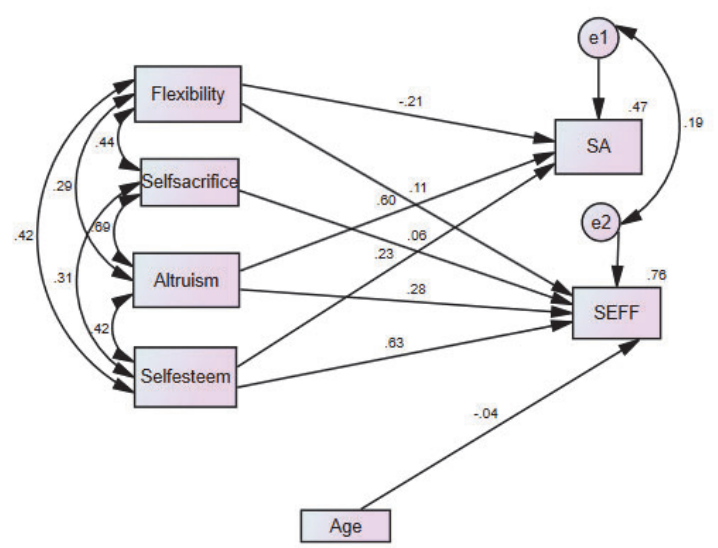


FIGURE C2

FIRE FIGHTER SEM

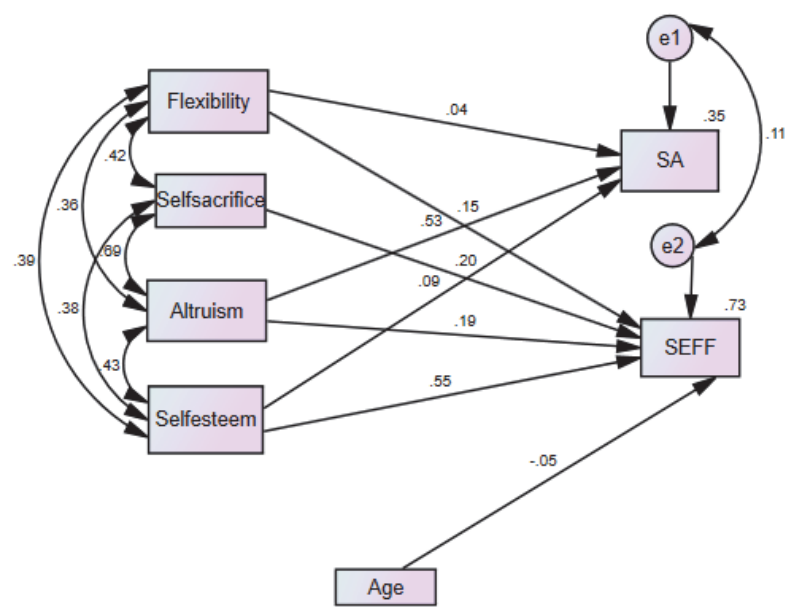

FIGURE C3

LAW ENFORCEMENT SEM

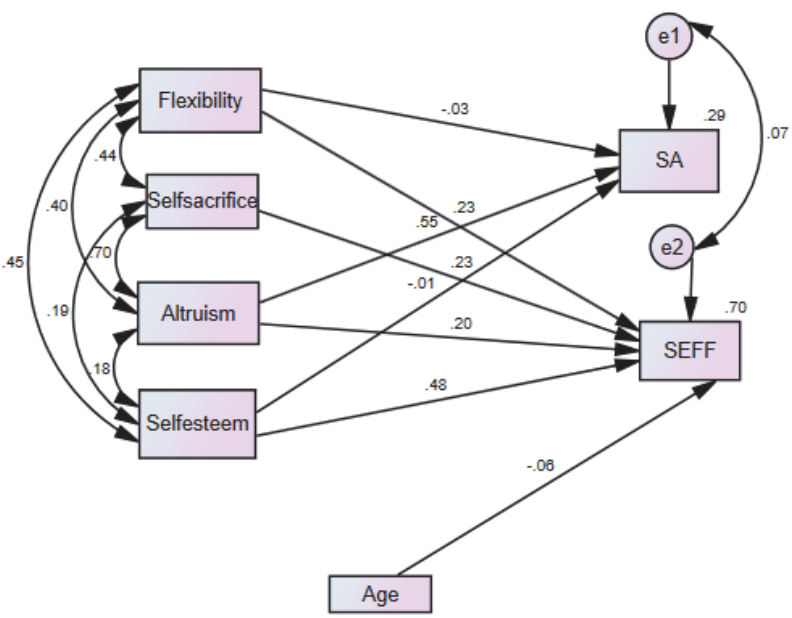

